\title{
Crop nutrition and fertilizer management of embryo-cultured seedlings of Makapuno and Laguna Tall coconuts with special reference to their response to different levels of $\mathrm{NaCl}$ and chicken manure
}

\author{
M.B. Areza-Ubaldo ${ }^{1}$, S.S. Magat ${ }^{2}$, E.P. Rillo ${ }^{3}$, and M.I. Secretaria ${ }^{4}$
}

\begin{abstract}
A two-year nursery study of embryo-cultured Laguna Tall (ECLAGT) and embryo-cultured Makapuno Tall (ECMAKT) coconut seedlings was conducted at the Philippine Coconut Authority Albay Research Center, Guinobatan, Albay aimed to know the effects of applying different levels of sodium chloride $(\mathrm{NaCl})$ (common table salt) and chicken manure $(\mathrm{CM})$ on the vegetative growth and leaf nutrient status of the seedlings. The soil used in the study is a volcanic ash- rich Guinobatan silt loam, classified as Entic Dystrandept soil subgroup (U.S. Soil Taxonomy/Classification).

EC seedlings with the application of $\mathrm{NaCl}$ at a total dose of $18-54 \mathrm{~g} /$ seedling and chicken manure at 250-750 g/seedling, applied within the 12-month nursery (at intervals of 2,4,6,8,10 months) significantly produced taller seedlings with bigger girth and more total living fronds than the unfertilized ECLAGT and ECMAKT seedlings. The levels of nutrient application (fertilization) on EC seedlings is clearly much lower than that of the average rates used in growing ordinary seedlings from seednuts, i.e. seedling with embryo attached to the whole nut in the nursery.

The better growth of ECLAGT and ECMAKT seedlings in terms of their girth, plant height and total living fronds produced was significantly associated with higher or very satisfactory levels of leaf $\mathrm{N}, \mathrm{P}, \mathrm{K}, \mathrm{Cl}, \mathrm{Ca}, \mathrm{Na}, \mathrm{Mg}, \mathrm{S}, \mathrm{B}$, and Fe (leaf \#4 of 12-month old EC seedlings).

The overall results clearly indicate the practical need to apply a combination of sodium chloride and dried chicken manure, even at moderate rates (total) of $18 \mathrm{~g} / \mathrm{seedling}$ and $250 \mathrm{~g} / \mathrm{seedling}$ respectively, divided equally during the 12-month nursery stage for normal growth and proper nutrition of EC seedlings. This recommended fertilization management practice should ensure healthy and good quality ECMAKT seedlings as planting materials.
\end{abstract}

Key words: Embryo cultured Laguna Tall (ECLAGT), embryo cultured Makapuno Tall (ECMAKT), sodium chloride (common table salt), chicken manure, macronutrient, micronutrients.

\footnotetext{
${ }^{1}$ Sc. Research Specialist II, PCA-Albay Research Center, Guinobatan, Albay, e-mail address: mbbareza@globalink.ph

${ }^{2}$ Manager, Agricultural Research Management Dept, \& Scientist IV, PCA-Diliman, Quezon City, e-mail address: sev_magat@yahoo.com

${ }^{3}$ Division Chief III and Scientist IV, PCA-Albay Research Center, Guinobatan, Albay, e-mail address: eprillo@globalink.ph or indayrillo@yahoo.com

${ }^{4}$ Sc. Research Specialist II and Scientist I, PCA-Davao Research Center, Bago Oshiro, Davao City, e-mail address: pcaasd@pldtdsl.net or milsecretaria@yahoo.com
} 


\section{Introduction}

A protocol to mass produce embryo cultured seedlings of Makapuno Tall variety of coconut palm had been optimized by the Coconut Tissue Culture Team of the Philippine Coconut Authority at the Albay Research Center (PCA$\mathrm{ARC}$ ). This technique has been used by many other commercial embryo culture laboratories in the country. However, to optimize growth and development of these seedlings through integrated crop management (ICM), the balanced nutrient requirement during the nursery period deserves a close investigation.

Research findings on the mineral nutrition and maintenance and corrective fertilizer applications conducted by PCA (Magat and Margate, 1990; Margate and Magat, 1991) clearly showed that the main nutrients needed by coconut areas are nitrogen $(\mathrm{N})$, chlorine $(\mathrm{Cl})$, potassium $(\mathrm{K})$ and sulfur $(\mathrm{S})$. In recent years, Magat (1999) had included the need for micronutrient boron (B) extensively in the Philippines. Cheaper but efficient sources of nutrients like chicken manure and common salt $(\mathrm{NaCl})$ for the embryo cultured coconut seedlings need to be studied.

The fertilizer requirement of seedlings produced from the commonly germinated seednuts is very different from the embryo cultured grown seedlings. This is mainly due to the inherent physiological and morphological differences of these two seedlings grown under entirely different conditions. Seedlings of the former are usually bigger and stronger as these grow and develop under normal conditions. In contrast, the latter are commonly smaller and more fragile since these are initially germinated under controlled laboratory conditions where nutrition and growing conditions are artificial. Earlier experiments on the application of different rates of organic NPK "complete" solid fertilizer and a foliar fertilizer on embryo cultured (EC) Makapuno seedlings, strongly indicated that levels of nutrient application was much lower (6-9 g NPK/seedling) than the average rates commonly used in ordinarily raised seedlings in the nursery stage (250-300 g NPK/seedling) (Areza-Ubaldo et al., 2005).

The application of common salt at 50-60 $\mathrm{g} /$ seedlings was recommended and became a common practice for growing ordinary seedlings in the nursery (Magat et al., 1977; Magat and Margate, 1990; Margate and Magat, 1991; and Magat, 1999). On the other hand, the use of chicken manure (CM) or poultry manure on coconut was earlier studied and found effective on coconut at different growth stages (Cadigal et al., 1986; Secretaria and Maravilla, 1997). Considering that common salt or sodium chloride is an effective and cheaper source of $\mathrm{Cl}$ macronutrient, and $\mathrm{CM}$ as a source of several micronutrients particularly sulphur for coconut, its optimum combination should be a cheaper source of nutrients and practical for the successful establishment of embryo cultured seedlings in the soil.

This research work was conducted for 2 years (2004-2005) at the PCA-Albay Research Center, Guinobatan, Albay. The Province of Albay is one of the major coconut-producing areas, adjacent to many large coconut-producing provinces in the Bicol Region, far south of Metro Manila. The objectives of the study are to determine the nutrient requirement and fertilizer needs of embryo cultured (EC) coconut seedlings and their fertilizer management system during the early stages of development and to know the effects of different rates of sodium chloride (common salt) in combination with different rates of chicken manure (CM) on the vegetative growth and nutrient status of EC seedlings.

\section{Materials and methods}

Initially, the experimental materials used were 4 month-old embryo-cultured Makapuno Tall (ECMAKT) seedlings produced at the PCA-ARC laboratory. At this stage, the seedlings have 3-4 expanded leaves and with profuse secondary and tertiary roots before they were potted-out in sterile sand. 
ECMAKT seedlings were taken out from the laboratory and hardened in the screen-house for one week. After the desired period, these were potted-out in small polybags $(7 \times 11)$ " containing $100 \%$ sterilized sand (Rillo and Paloma, 1992) and incubated in the screen-house $(\mathrm{SH})$ for 2 months without any fertilizer application.

A preliminary trial using a combination of $10-30 \mathrm{~g} /$ seedling of $\mathrm{NaCl}$ and $200 \mathrm{~g} /$ seedling of $\mathrm{CM}$ was conducted. Fertilizer treatments (replicated 3 times, with 9 seedlings per replicate per treatment) were applied starting on the 2nd month of the establishment. Seedlings were transferred to bigger polybags (12x12)" containing topsoil and sand at 1:1 ratio to reduce the disturbance to the seedling root system during its growth and development. Subsequently, seedlings were incubated under nursery conditions.

Three days after fertilizer application, all the ECMAKT seedlings died due to high amounts of $\mathrm{NaCl}$ and $\mathrm{CM}$ contained in the original application rates. This result showed that the requirement of embryo cultured coconut seedlings for common salt and CM should be lower than the rates used for normal coconut seedlings from germinated seednuts. Thus, the treatments were modified in another trial at the 2 , $4,6,8$, and 10-month growth stages of the EC seedlings (Table 1).

For the formal experiment, 4 month-old ECLAGT and ECMAKT seedlings, with 3-4 expanded leaves and profuse roots were produced in the laboratory prior to potting-out. The protocol developed at PCA-ARC (Rillo and Paloma, 1992) for the ex vitro establishment of coconut seedlings was used. EC seedlings of Laguna Tall variety were used in Trial 1 in order to determine the response to $\mathrm{NaCl}$ and $\mathrm{CM}$ applications of EC seedlings from normal Tall variety producing normal (firm fresh meat) nuts. Moreover, the effect of $\mathrm{NaCl}$ and $\mathrm{CM}$ at modified rates is still unknown; hence, EC seedling from normal coconuts was also tested. As the ECLAGT seedlings showed positive response to the modified fertilizer treatments, another coconut variety with higher commercial value
(ECMAKT) was used in the second trial. MAKT variety in its normal feature produces nuts with soft fresh meat (endosperm) which is processed to high value food products. EC Makapuno seedlings were used in Trial 2 as the fertilizer requirement of ECMAKT seedlings grown with soil in the nursery polybag also needs to be optimized for maximum economic benefit.

The Makapuno seedlings (preliminary trial) died even at lowest rates of $\mathrm{NaCl}$ and $\mathrm{CM}$ used. Hence, the rate used in the follow-up trials was a range lower than $10 \mathrm{~g} /$ seedling and 200 $\mathrm{g} /$ seedling, respectively. This time, the effect of the modified fertilizer treatments (Table 1) was considered. Trial 1 with ECLAGT and Trial 2 with ECMAKT seedlings were both laid out in randomized complete block design (RCBD) with three (3) replicates and 9 and 15 seedlings per replicate per treatment, respectively.

After 12 months, leaf samples (frond \#4) from 9 and 15 seedlings per replicate per treatment from ECLAGT and ECMAKT, respectively were collected, dried for 8 hours (at $60^{\circ} \mathrm{C}$ ) prior to submission for leaf analysis at the Plant and Soil Analysis Laboratory in PCACentral Office, Quezon City, for macro- and micronutrients. Dried sample of chicken manure $(500 \mathrm{~g})$ was also sent for nutrient analysis (Table 2).

Data on vegetative growth characters (girth, plant height and total living fronds) were recorded every 2 months for 12 months. Trials 1 and 2 were conducted separately; hence, data on vegetative growth characters and leaf nutrients from these 2 trials were analyzed separately using RCBD and Duncan's Multiple Range Test (DMRT) for the comparison of significant treatment means.

\section{Results and discussion}

\section{A. Effect on vegetative growth of embryo cultured seedlings}

Based on the statistical analysis of results (Table 3), there was significant difference 
among the fertilizer treatments in terms of girth of ECLAGT seedlings (Trial 1) and ECMAKT seedlings (Trial 2). ECLAGT seedlings had the biggest girth size with fertilizer treatments FT1 and FT2 on the 12th month, but FT2 is not significantly different from FT3. ECMAKT (Figure 1) seedlings had the biggest girth, with EC seedlings under treatments FT1, FT2 and FT3 producing similar girth and were significantly bigger than unfertilized EC seedlings.

In terms of seedling height, significant differences among the fertilizer treatments were noted, starting with 6th -12 th month growth stage of EC seedlings of the 2 cultivars tested. On the 12th month, ECLAGT and ECMAKT (Figure 1) seedlings fertilized with any combination of $\mathrm{NaCl}$ and $\mathrm{CM}$ produced significantly taller seedlings over the unfertilized EC seedlings. The height differences of ECLAGT and ECMAKT seedlings under the treatments FT1, FT2 and FT3 were not statistically significant.

A significant difference among the fertilizer treatments in terms of total number of living fronds of EC seedlings was noted for both the cultivars tested, except at the earliest growth stage of the 2 month old ECMAKT seedlings (Table 5). In the 12th month, the total number of living fronds from both cultivars were highest with EC seedlings fertilized with combinations of $\mathrm{NaCl}$ and $\mathrm{CM}$ (treatments FT1, FT2 and FT3). But, among these treatments, the number of living fronds of EC seedlings for both cultivars was not significantly different.
In general, results showed that significantly better vegetative growth (girth, height and living fronds) of embryo cultured seedlings of Laguna Tall (ECLAGT) and Makapuno Tall (ECMAKT) were obtained with the application of combinations of common salt and chicken manure, compared to the unfertilized seedlings. This was clearly indicated particularly at the 12month growth stage of EC seedlings for both cultivars used. Results indicated strongly that at moderate rates of common salt $(\mathrm{NaCl})$ at $18 \mathrm{~g}$ per seedling and $\mathrm{CM}$ at $250 \mathrm{~g}$ per seedling can be highly recommended to obtain the best growth of seedlings under the growing conditions of the study, using the local typical soil (volcanic ash-rich Guinobatan silt loam) at the PCA-ARC .

As shown in Tables 3-5, between the two treated EC seedlings, the ECMAKT seedlings were appreciably better in terms of girth, seedling height and total living fronds under higher rates of application of $\mathrm{NaCl}$ and $\mathrm{CM}$ (FT2 and FT3). In the case of ECLAGT seedlings, much better ones were produced at the lower rates of fertilizer application of $\mathrm{NaCl}$ and CM (FT1).

Thus, to optimize the growth and development of ECMAKT seedlings, higher rates of common salt and chicken manure application (54 g NaCl and $750 \mathrm{~g} \mathrm{CM}$ per seedling) is required for a healthy, good quality ECMAKT planting material. In contrast, the ECLAGT seedlings required only the lowest rates of $18 \mathrm{~g} \mathrm{NaCl}$ and $250 \mathrm{~g} \mathrm{CM}$ per seedling for realizing desired growth of EC seedlings.

Table 1. Modified common salt $(\mathrm{NaCl})$ and chicken manure $(\mathrm{CM})$ treatments for embryo cultured coconut seedlings grown in the screen-house and nursery

\begin{tabular}{|c|c|c|c|c|c|}
\hline \multirow{2}{*}{$\begin{array}{l}\text { Growth stage of EC } \\
\text { seedling }\end{array}$} & \multirow[t]{2}{*}{ Source of nutrients } & \multicolumn{4}{|c|}{$\begin{array}{l}\text { Fertilizer treatments }(\mathrm{FT}) \\
(\mathrm{g} / \text { seedling })\end{array}$} \\
\hline & & FT0 & FT1 & FT2 & FT3 \\
\hline \multirow{2}{*}{ At 2 months } & $\mathrm{NaCl}$ & 0 & 2 & 4 & 6 \\
\hline & $\mathrm{CM}$ & 0 & 50 & 100 & 150 \\
\hline \multirow{2}{*}{$\begin{array}{l}\text { At } 4,6,8, \& 10 \\
\text { months }\end{array}$} & $\mathrm{NaCl}$ & 0 & 4 & 8 & 12 \\
\hline & $\mathrm{CM}$ & 0 & 50 & 100 & 150 \\
\hline \multirow{2}{*}{ Total (Nursery) } & $\mathrm{NaCl}$ & $\mathbf{0}$ & 18 & 36 & 54 \\
\hline & CM & $\mathbf{0}$ & 250 & 500 & 750 \\
\hline
\end{tabular}


Table 2. Content of nutrients of chicken manure used in the experiment (Analysis by PTAL, Plant and Soil Analysis Laboratory, Central Office, PCA)

\begin{tabular}{|c|c|c|c|c|c|c|c|c|}
\hline \multicolumn{9}{|c|}{ Per cent $(\%)$ in dry matter } \\
\hline $\mathrm{N}^{\mathrm{a}}$ & $\mathrm{P}$ & $\mathrm{K}$ & $\mathrm{Ca}$ & $\mathrm{Mg}$ & $\mathrm{Na}$ & $\mathrm{Cl}^{\mathrm{b}}$ & $\mathrm{S}$ & $\mathrm{OM}^{\mathrm{c}}$ \\
\hline 3.32 & 0.60 & 1.56 & 14.75 & 1.62 & 0.45 & 0.60 & 0.58 & 38.70 \\
\hline
\end{tabular}

${ }^{\mathrm{a}}$ Total $\left(\mathrm{NH}_{4}^{+}, \mathrm{NO}_{3}^{-}\right) \quad{ }^{\mathrm{b}}$ Water-soluble $\quad{ }^{\mathrm{c}}$ Dry-ashing method

Table 3. Effect of different fertilizer treatments on girth size of embryo cultured seedlings cvs. Laguna Tall (Trial 1) and Makapuno Tall (Trial 2) at different nursery growth stages (PCA-Albay Research Center, 2005)

\begin{tabular}{|c|c|c|c|c|c|c|c|c|}
\hline \multirow{2}{*}{ Cultivar } & \multirow{2}{*}{$\begin{array}{l}\text { Fertilizer } \\
\text { Treatment }\end{array}$} & \multirow{2}{*}{ Initial $^{\#}$} & \multicolumn{6}{|c|}{ Months } \\
\hline & & & 2 & 4 & 6 & 8 & 10 & 12 \\
\hline \multicolumn{9}{|c|}{ Girth size $(\mathrm{cm})$} \\
\hline \multirow{6}{*}{ ECLAGT } & FT0 & $3.8 \mathrm{a}$ & $4.2 \mathrm{a}$ & $4.2 \mathrm{c}$ & $4.4 \mathrm{c}$ & $5.1 \mathrm{c}$ & $5.5 \mathrm{c}$ & $5.8 \mathrm{c}$ \\
\hline & FT1 & $3.1 \mathrm{~b}$ & $3.7 \mathrm{~b}$ & $5.5 \mathrm{a}$ & $6.2 \mathrm{a}$ & $6.7 \mathrm{a}$ & $8.3 \mathrm{a}$ & $8.7 \mathrm{a}$ \\
\hline & FT2 & $3.3 \mathrm{ab}$ & $3.4 \mathrm{~b}$ & $4.7 \mathrm{~b}$ & $5.6 \mathrm{~b}$ & $6.1 \mathrm{~b}$ & $6.5 \mathrm{~b}$ & $7.8 \mathrm{ab}$ \\
\hline & FT3 & $3.7 \mathrm{ab}$ & $4.1 \mathrm{a}$ & $4.5 \mathrm{bc}$ & $4.7 \mathrm{c}$ & $6.6 \mathrm{ab}$ & $7.5 \mathrm{a}$ & $7.7 \mathrm{~b}$ \\
\hline & Mean & 3.5 & 3.9 & 4.7 & 5.2 & 6.1 & 6.9 & 7.5 \\
\hline & $\begin{array}{c}\text { Level of } \\
\text { significance }\end{array}$ & ns & $*$ & $* *$ & $* *$ & $* *$ & $* *$ & $* *$ \\
\hline \multirow{6}{*}{ ECMAKT } & FT0 & $2.8 \mathrm{a}$ & $3.2 \mathrm{a}$ & $3.3 \mathrm{a}$ & $3.4 \mathrm{~b}$ & $3.8 \mathrm{c}$ & $4.3 \mathrm{~b}$ & $4.8 \mathrm{~b}$ \\
\hline & FT1 & $2.7 \mathrm{a}$ & $3.2 \mathrm{ab}$ & $3.3 \mathrm{a}$ & $3.6 \mathrm{ab}$ & $4.7 \mathrm{~b}$ & $5.8 \mathrm{a}$ & $6.8 \mathrm{a}$ \\
\hline & FT2 & $2.7 \mathrm{a}$ & $3.1 \mathrm{~b}$ & $3.3 \mathrm{a}$ & $3.9 \mathrm{a}$ & $5.2 \mathrm{a}$ & $6.3 \mathrm{a}$ & $7.2 \mathrm{a}$ \\
\hline & FT3 & $2.7 \mathrm{a}$ & $3.1 \mathrm{~b}$ & $3.3 \mathrm{a}$ & $4.0 \mathrm{a}$ & $4.9 \mathrm{ab}$ & $6.4 \mathrm{a}$ & $7.1 \mathrm{a}$ \\
\hline & Mean & 2.7 & 3.1 & 3.3 & 3.7 & 4.7 & 5.7 & 6.5 \\
\hline & $\begin{array}{c}\text { Level of } \\
\text { significance }\end{array}$ & $\mathrm{ns}$ & $*$ & ns & $*$ & $* *$ & $* *$ & $* *$ \\
\hline
\end{tabular}

${ }^{\#}$ Before fertilizer treatment

Treatment means with the same letter(s) are not significantly different from each other at 5\% level (Duncan's Multiple Range Test [DMRT]). 


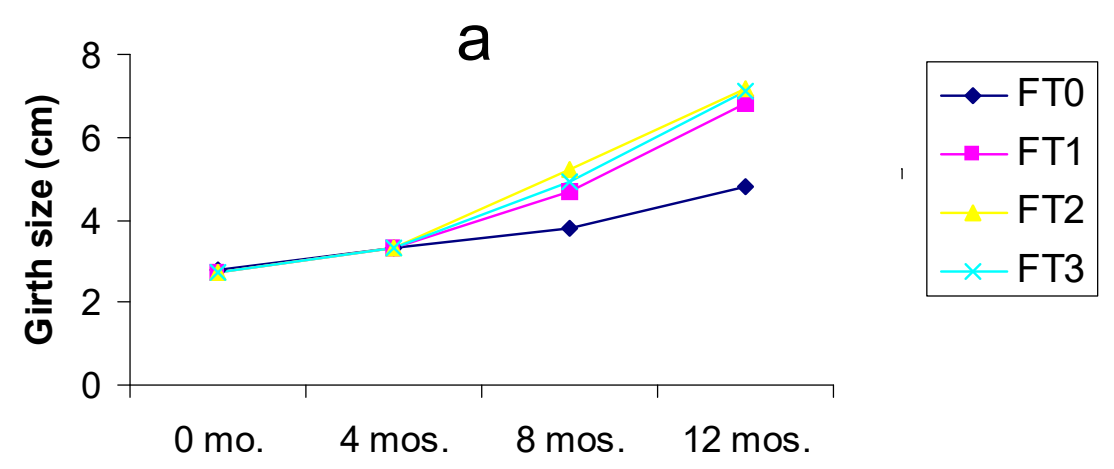

Growth stage

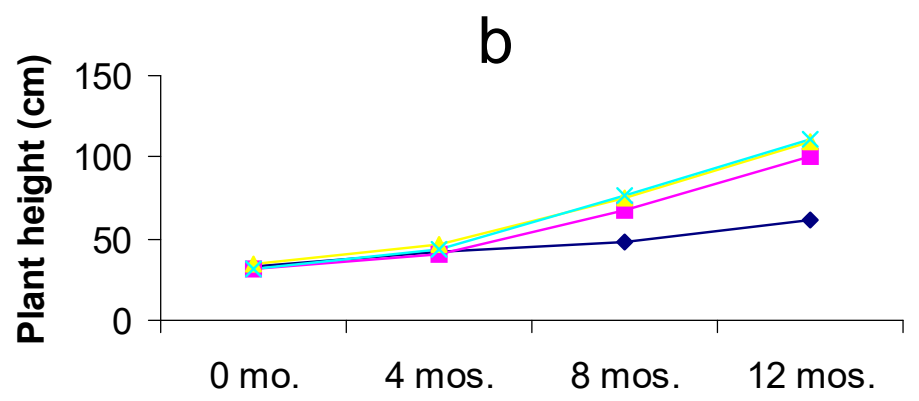

Growth stage

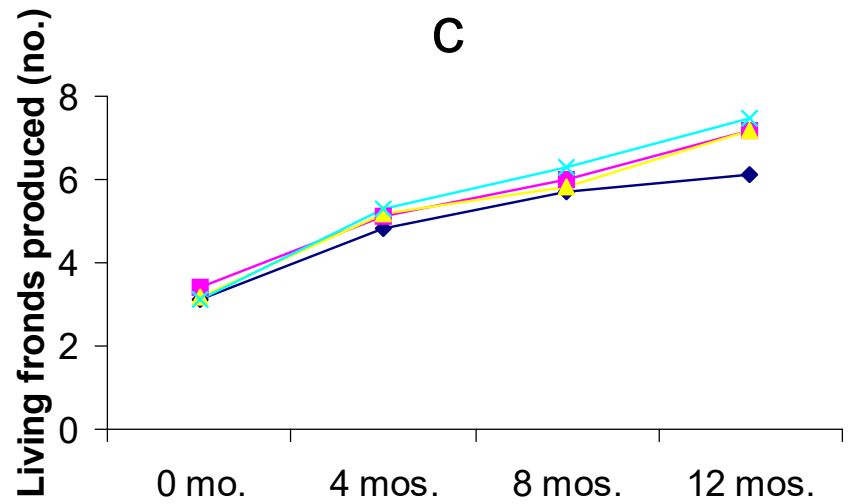

Growth stage

Fig. 1. Effects of fertilizer treatments on (a) girth size, (b) plant height and (c) total living fronds produced of ECMAKT seedlings at different growth stages (PCA-ARC, Albay, 2005). 

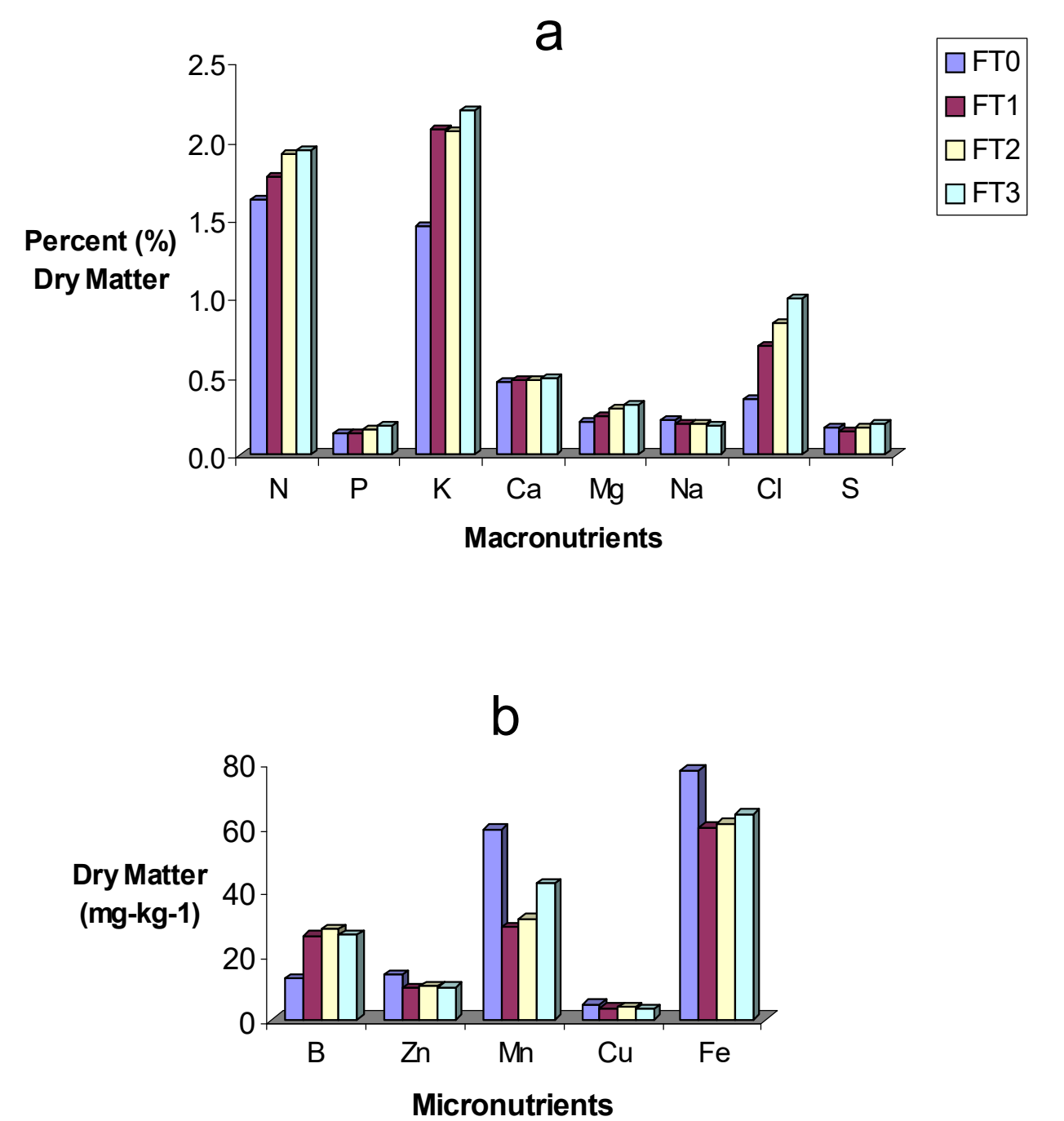

Fig. 2. Effects of fertilizer treatments on leaf (a) macronutrients and (b) micronutrients levels of ECMAKT seedlings at 12 months (PCA-ARC, Albay, 2005). 
Table 4. Effects of different fertilizer treatments on plant height of embryo cultured seedlings cvs. Laguna Tall (Trial 1) and Makapuno Tall (Trial 2) at different nursery growth stages (PCA-Albay Research Center, 2005)

\begin{tabular}{|c|c|c|c|c|c|c|c|c|}
\hline \multirow{2}{*}{ Cultivar } & \multirow{2}{*}{$\begin{array}{l}\text { Fertilizer } \\
\text { treatment }\end{array}$} & \multirow{2}{*}{ Initial $^{\#}$} & \multicolumn{5}{|c|}{ Months } & \multirow[b]{2}{*}{12} \\
\hline & & & 2 & 4 & 6 & 8 & 10 & \\
\hline \multicolumn{9}{|c|}{ Plant Height $(\mathrm{cm})$} \\
\hline \multirow{6}{*}{ ECLAGT } & FT0 & $46.8 \mathrm{a}$ & $48.6 \mathrm{a}$ & $48.5 \mathrm{c}$ & $51.4 \mathrm{c}$ & $56.3 \mathrm{c}$ & $71.2 \mathrm{~b}$ & $83.8 \mathrm{~b}$ \\
\hline & FT1 & $46.4 \mathrm{a}$ & $50.0 \mathrm{a}$ & $62.9 \mathrm{a}$ & $82.6 \mathrm{a}$ & $110.3 \mathrm{a}$ & $129.0 \mathrm{a}$ & $140.8 \mathrm{a}$ \\
\hline & FT2 & $42.5 \mathrm{a}$ & $46.0 \mathrm{a}$ & $53.0 \mathrm{bc}$ & $68.9 \mathrm{~b}$ & $79.3 \mathrm{~b}$ & $88.8 \mathrm{~b}$ & $115.1 \mathrm{a}$ \\
\hline & FT3 & $41.7 \mathrm{a}$ & $46.0 \mathrm{a}$ & $58.8 \mathrm{ab}$ & $67.4 \mathrm{~b}$ & $89.7 \mathrm{ab}$ & $117.1 \mathrm{a}$ & $135.9 \mathrm{a}$ \\
\hline & Mean & 44.4 & 47.7 & 55.8 & 67.6 & 83.9 & 101.5 & 118.9 \\
\hline & $\begin{array}{c}\text { Level of } \\
\text { significance }\end{array}$ & ns & ns & ns & $* *$ & $* *$ & $* *$ & $* *$ \\
\hline \multirow{6}{*}{ ECMAKT } & FT0 & $32.8 \mathrm{ab}$ & $38.4 \mathrm{a}$ & $41.4 \mathrm{~b}$ & $45.4 \mathrm{~b}$ & $48.2 \mathrm{c}$ & $56.3 \mathrm{c}$ & $61.7 \mathrm{~b}$ \\
\hline & FT1 & $31.8 \mathrm{~b}$ & $36.8 \mathrm{a}$ & $40.6 \mathrm{~b}$ & $51.0 \mathrm{a}$ & $67.4 \mathrm{~b}$ & $85.4 \mathrm{~b}$ & $100.3 \mathrm{a}$ \\
\hline & FT2 & $34.1 \mathrm{a}$ & $40.3 \mathrm{a}$ & $46.4 \mathrm{a}$ & $55.3 \mathrm{a}$ & $75.7 \mathrm{a}$ & $96.7 \mathrm{ab}$ & $110.0 \mathrm{a}$ \\
\hline & FT3 & $32.2 \mathrm{ab}$ & $38.3 \mathrm{a}$ & $43.6 \mathrm{ab}$ & $55.5 \mathrm{a}$ & $76.4 \mathrm{a}$ & $100.9 \mathrm{a}$ & $110.7 \mathrm{a}$ \\
\hline & Mean & 44.4 & 47.7 & 55.8 & 67.6 & 83.9 & 101.5 & 118.9 \\
\hline & $\begin{array}{c}\text { Level of } \\
\text { significance }\end{array}$ & ns & ns & ns & $* *$ & $* *$ & $* *$ & $* *$ \\
\hline
\end{tabular}

${ }^{\#}$ Before fertilizer treatment

Treatment means with the same letter(s) are not significantly different from each other at 5\% level (Duncan's Multiple Range Test [DMRT]).

Table 5. Effects of different fertilizer treatments on the total no. of living fronds of embryo cultured seedlings cvs. Laguna Tall (Trial 1) and Makapuno Tall (Trial 2) at different nursery growth stages (PCAAlbay Research Center, 2005)

\begin{tabular}{|c|c|c|c|c|c|c|c|c|}
\hline \multirow{2}{*}{ Cultivar } & \multirow{2}{*}{$\begin{array}{l}\text { Fertilizer } \\
\text { treatment }\end{array}$} & \multirow{2}{*}{ Initial $^{\#}$} & \multicolumn{6}{|c|}{ Months } \\
\hline & & & 2 & 4 & 6 & 8 & 10 & 12 \\
\hline \multicolumn{9}{|c|}{ Total Living Fronds (no.) } \\
\hline \multirow{6}{*}{ ECLAGT } & FT0 & $3.6 \mathrm{c}$ & $4.4 \mathrm{~b}$ & $5.2 \mathrm{c}$ & $4.9 \mathrm{c}$ & $4.6 \mathrm{c}$ & $5.8 \mathrm{c}$ & $6.7 \mathrm{~b}$ \\
\hline & FT1 & $4.1 \mathrm{bc}$ & $5.6 \mathrm{a}$ & $7.1 \mathrm{a}$ & $8.1 \mathrm{a}$ & $6.5 \mathrm{~b}$ & $7.5 \mathrm{~b}$ & $7.8 \mathrm{a}$ \\
\hline & FT2 & $4.7 \mathrm{a}$ & $5.6 \mathrm{a}$ & $6.9 \mathrm{a}$ & $8.1 \mathrm{a}$ & $8.4 \mathrm{a}$ & $8.8 \mathrm{a}$ & $8.2 \mathrm{a}$ \\
\hline & FT3 & $4.2 \mathrm{ab}$ & $4.7 \mathrm{~b}$ & $5.9 \mathrm{~b}$ & $6.4 \mathrm{~b}$ & $6.8 \mathrm{~b}$ & $7.7 \mathrm{~b}$ & $8.2 \mathrm{a}$ \\
\hline & Mean & 4.1 & 5.1 & 6.2 & 6.9 & 6.6 & 7.5 & 7.7 \\
\hline & $\begin{array}{c}\text { Level of } \\
\text { significance }\end{array}$ & $*$ & $* *$ & $* *$ & $* *$ & $* *$ & $* *$ & $*$ \\
\hline \multirow{6}{*}{ ECMAKT } & FT0 & $3.1 \mathrm{~b}$ & $4.4 \mathrm{a}$ & $4.8 \mathrm{~b}$ & $5.1 \mathrm{~b}$ & $5.7 \mathrm{~b}$ & $5.4 \mathrm{~b}$ & $6.1 \mathrm{~b}$ \\
\hline & FT1 & $3.4 \mathrm{a}$ & $4.1 \mathrm{a}$ & $5.1 \mathrm{ab}$ & $5.5 \mathrm{~b}$ & $6.0 \mathrm{ab}$ & $6.7 \mathrm{a}$ & $7.2 \mathrm{a}$ \\
\hline & FT2 & $3.2 \mathrm{ab}$ & $4.3 \mathrm{a}$ & $5.2 \mathrm{a}$ & $6.6 \mathrm{a}$ & $5.8 \mathrm{~b}$ & $6.6 \mathrm{a}$ & $7.2 \mathrm{a}$ \\
\hline & FT3 & $3.1 \mathrm{~b}$ & $4.4 \mathrm{a}$ & $5.3 \mathrm{a}$ & $6.5 \mathrm{a}$ & $6.3 \mathrm{a}$ & $7.0 \mathrm{a}$ & $7.5 \mathrm{a}$ \\
\hline & Mean & 3.2 & 4.3 & 5.1 & 6.0 & 5.9 & 6.5 & 7.0 \\
\hline & $\begin{array}{c}\text { Level of } \\
\text { significance }\end{array}$ & Ns & ns & $*$ & $* *$ & $*$ & $*$ & $* *$ \\
\hline
\end{tabular}

\# Before fertilizer treatment

Treatment means with the same letter(s) are not significantly different from each other at 5\% level (Duncan's Multiple Range Test [DMRT ]). 


\section{B. Leaf nutrient levels of embryo cultured seedlings}

Results of statistical analyses of leaf macronutrient levels of leaf rank no. 4, showed significant treatment effect on leaf $\mathrm{N}, \mathrm{P}, \mathrm{K}, \mathrm{Cl}$ and $\mathrm{S}$ of the 2 cultivars tested (Table 6 ).

FT3 was significantly different from the other treatments in terms of leaf $\mathrm{N}, \mathrm{P}$ and $\mathrm{Cl}$. Results show that the treatment of ECLAGT and ECMAKT seedlings with $\mathrm{NaCl}$ and chicken manure at $54 \mathrm{~g} / \mathrm{seedling}$ and $750 \mathrm{~g} /$ seedling, respectively (FT3) increased leaf $\mathrm{N}, \mathrm{P}$ and $\mathrm{Cl}$ more than the other treatments.

EC seedlings from both cultivars treated with low levels of $\mathrm{NaCl}$ and chicken manure (FT1 and FT2) gave the highest leaf K and were significantly different from FT0 and FT3. This indicates that application of $\mathrm{NaCl}$ at highest rate tended to depress the leaf $\mathrm{K}$ concentration, a likely $\mathrm{K}-\mathrm{Na}$ antagonism reaction in EC seedlings.

The good vegetative growth noted in fertilized seedlings indicate that they responded positively to the application of chicken manure because of its capability to supply significant amounts of $\mathrm{N}(3.32 \%), \mathrm{P}(0.60 \%), \mathrm{K}(1.56 \%)$, and $\mathrm{Cl}(0.60 \%)$ (Table 2). Common sea salt application provided the EC seedlings an increased supply of $\mathrm{Na}$ and $\mathrm{Cl}$ nutrients. These results support earlier findings that $\mathrm{Cl}$ application significantly increased the girth of seedlings at nursery stage (Magat et al., 1977; Oguis et al., 1979; Magat and Prudente, 1975) mentioned by Maravilla (1986).

Significant effect of fertilizer treatments was also noted in terms of leaf $\mathrm{Ca}$ and $\mathrm{Na}$ from ECLAGT and leaf Mg from ECMAKT seedlings. ECLAGT seedlings fertilized with FT1 and FT2 increased leaf $\mathrm{Ca}$, significantly different from the other treatments. High rates of application of $\mathrm{NaCl}$ and $\mathrm{CM}$ treatments (FT2 and FT3) resulted in highest leaf $\mathrm{Na}$ in ECLAGT seedlings and the highest leaf $\mathrm{Mg}$ and $\mathrm{S}$ in ECMAKT seedlings, significantly different from the other fertilizer treatments.

Results also indicate that the treatments with chicken manure increased contents of most leaf nutrients. This is attributed to substantial contents of nutrients in the CM: Ca $(14.75 \%)$, $\mathrm{Na}(0.45 \%), \mathrm{Mg}(1.61 \%)$, and S (0.58\%) (Table $2)$, which contributed to the impressive vegetative growth of the EC seedlings in the nursery.

The highest leaf $\mathrm{S}$ was noted from the unfertilized (FT0) ECLAGT seedlings, which was significantly different from the other treatments. This means that the amount of sulphur obtained from $\mathrm{Fe}_{2} \mathrm{SO}_{4} \cdot 7 \mathrm{H}_{2} \mathrm{O}$ in the growth medium during the in vitro culture of EC Laguna Tall seedlings is sufficient to give optimum response during their later growth under $e x$-vitro conditions.

Leaf B of EC seedlings of LAGT and MAKT (Figure 2b) cultivars was significantly higher with $\mathrm{NaCl}$ and $\mathrm{CM}$ fertilization, but leaf B levels of fertilized EC seedlings (FT1, FT2 and FT3) in both cultivars were not significantly different (Table 7). In both cultivars, leaf $\mathrm{Zn}$ and $\mathrm{Cu}$ of EC seedlings were not significantly affected by the fertilizer application, but leaf $\mathrm{Mn}$ were significantly reduced in contrast, even at the lowest rates of fertilizer application. However, leaf $\mathrm{Fe}$ of ECLAGT seedlings significantly increased under FT1 and FT2 fertilizer treatments. The observed increases in concentrations of leaf $\mathrm{B}$ and $\mathrm{Fe}$ in the $\mathrm{EC}$ seedlings is strongly attributed to the chicken manure component of the fertilizer application (Table 2). Magat and Recel (2000) noted that chicken manure from several sources in the country contain high amounts of micronutrients (B, 45 ppm; Fe, 27,600 ppm; Zn, 589 ppm; $\mathrm{Cu}$, $116 \mathrm{ppm}$; and $\mathrm{Mn}, 1,700 \mathrm{ppm}$. Moreover, the decrease in leaf $\mathrm{Mn}$ is suspected to be a possible 
Table 6. Leaf macronutrient levels (at leaf rank no. 4) of embryo cultured seedlings cvs. Laguna Tall (Trial 1) and Makapuno Tall (Trial 2) applied with different rates of sodium chloride (common salt) and chicken manure treatments at 12 months, PCA-ARC, 2005

\begin{tabular}{|c|c|c|c|c|c|c|c|c|c|}
\hline \multirow{2}{*}{ Cultivar } & \multirow{2}{*}{$\begin{array}{l}\text { Fertilizer } \\
\text { treatment }\end{array}$} & \multicolumn{8}{|c|}{ Dry matter $(\%)$} \\
\hline & & $\mathrm{N}$ & $\mathrm{P}$ & $\mathrm{K}$ & $\mathrm{Ca}$ & $\mathrm{Mg}$ & $\mathrm{Na}$ & $\mathrm{Cl}$ & $\mathrm{S}$ \\
\hline \multirow{5}{*}{ ECLAGT } & FT0 & $1.37 \mathrm{c}$ & $0.14 \mathrm{a}$ & $1.94 \mathrm{~b}$ & $0.47 \mathrm{~b}$ & $0.26 \mathrm{ab}$ & $0.11 \mathrm{c}$ & $0.50 \mathrm{~b}$ & $0.23 \mathrm{a}$ \\
\hline & FT1 & $1.58 \mathrm{~b}$ & $0.11 \mathrm{~b}$ & $2.29 \mathrm{a}$ & $0.76 \mathrm{a}$ & $0.29 \mathrm{a}$ & $0.30 \mathrm{~b}$ & $0.95 \mathrm{a}$ & $0.18 \mathrm{~b}$ \\
\hline & FT2 & $1.47 \mathrm{bc}$ & $0.11 \mathrm{~b}$ & $2.18 \mathrm{a}$ & $0.77 \mathrm{a}$ & $0.27 \mathrm{ab}$ & $0.36 \mathrm{a}$ & $0.98 \mathrm{a}$ & $0.19 \mathrm{~b}$ \\
\hline & FT3 & $1.79 \mathrm{a}$ & $0.12 \mathrm{ab}$ & $1.91 \mathrm{~b}$ & $0.48 \mathrm{~b}$ & $0.23 \mathrm{~b}$ & $0.31 \mathrm{ab}$ & $1.05 \mathrm{a}$ & $0.16 \mathrm{~b}$ \\
\hline & $\begin{array}{c}\text { Level of } \\
\text { Significance }\end{array}$ & $* *$ & $*$ & $*$ & $* *$ & ns & $* *$ & $* *$ & $* *$ \\
\hline \multirow{5}{*}{ ECMAKT } & FT0 & $1.62 \mathrm{c}$ & $0.14 \mathrm{~b}$ & $1.45 \mathrm{~b}$ & $0.46 \mathrm{a}$ & $0.20 \mathrm{c}$ & $0.22 \mathrm{a}$ & $0.36 \mathrm{~d}$ & $\begin{array}{c}0.16 \\
\mathrm{bc}\end{array}$ \\
\hline & FT1 & $1.76 \mathrm{~b}$ & $0.14 \mathrm{~b}$ & $2.06 \mathrm{a}$ & $0.48 \mathrm{a}$ & $0.25 \mathrm{~b}$ & $0.20 \mathrm{ab}$ & $0.69 \mathrm{c}$ & $0.15 \mathrm{c}$ \\
\hline & FT2 & $1.91 \mathrm{a}$ & $0.16 \mathrm{~b}$ & $2.05 \mathrm{a}$ & $0.48 \mathrm{a}$ & $0.29 \mathrm{a}$ & $0.20 \mathrm{ab}$ & $0.84 \mathrm{~b}$ & $\begin{array}{c}0.18 \\
a b\end{array}$ \\
\hline & FT3 & $1.94 \mathrm{a}$ & $0.19 \mathrm{a}$ & $2.19 \mathrm{a}$ & $0.48 \mathrm{a}$ & $0.31 \mathrm{a}$ & $0.19 \mathrm{~b}$ & $1.00 \mathrm{a}$ & $0.19 \mathrm{a}$ \\
\hline & $\begin{array}{c}\text { Level of } \\
\text { Significance }\end{array}$ & $* *$ & $*$ & $* *$ & ns & $* *$ & ns & $* *$ & $*$ \\
\hline
\end{tabular}

Treatment means with the same letter(s) are not significantly different from each other at 5\% level (Duncan's Multiple Range Test [DMRT ]).

Table 7. Leaf micronutrient levels (at leaf rank no. 4) of embryo cultured seedlings cvs. Laguna Tall (Trial 1) and Makapuno (Trial 2) applied with different rates of sodium chloride (common salt) and chicken manure at 12 months, PCA-ARC, 2005

\begin{tabular}{|c|c|c|c|c|c|c|}
\hline \multirow{2}{*}{ Cultivar } & \multirow{2}{*}{$\begin{array}{l}\text { Fertilizer } \\
\text { treatment }\end{array}$} & \multicolumn{5}{|c|}{ Dry matter $\left(\mathrm{mg}-\mathrm{kg}^{-1}\right)$} \\
\hline & & $\mathrm{B}$ & $\mathrm{Zn}$ & $\mathrm{Mn}$ & $\mathrm{Cu}$ & $\mathrm{Fe}$ \\
\hline \multirow{5}{*}{ ECLAGT } & FT0 & $14.00 \mathrm{~b}$ & $23.93 \mathrm{a}$ & $85.13 \mathrm{a}$ & $135.93 \mathrm{a}$ & $83.46 \mathrm{~b}$ \\
\hline & FT1 & $16.80 \mathrm{a}$ & $18.30 \mathrm{a}$ & $38.90 \mathrm{c}$ & $59.50 \mathrm{~b}$ & $96.50 \mathrm{ab}$ \\
\hline & FT2 & $16.96 \mathrm{a}$ & $19.86 \mathrm{a}$ & $53.30 \mathrm{~b}$ & $69.50 \mathrm{ab}$ & $112.40 \mathrm{a}$ \\
\hline & FT3 & $17.03 \mathrm{a}$ & $19.46 \mathrm{a}$ & $35.40 \mathrm{c}$ & $136.70 \mathrm{a}$ & $58.96 \mathrm{c}$ \\
\hline & $\begin{array}{c}\text { Level of } \\
\text { Significance }\end{array}$ & ns & ns & $* *$ & ns & $* *$ \\
\hline \multirow{5}{*}{ ECMAKT } & FT0 & $12.60 \mathrm{~b}$ & $13.76 \mathrm{a}$ & $59.23 \mathrm{a}$ & $4.76 \mathrm{a}$ & $77.60 \mathrm{a}$ \\
\hline & FT1 & $26.13 \mathrm{a}$ & $9.80 \mathrm{a}$ & $28.63 \mathrm{c}$ & $3.46 \mathrm{a}$ & $59.76 \mathrm{a}$ \\
\hline & FT2 & $28.23 \mathrm{a}$ & $10.16 \mathrm{a}$ & $31.50 \mathrm{c}$ & $3.73 \mathrm{a}$ & $61.10 \mathrm{a}$ \\
\hline & FT3 & $26.33 \mathrm{a}$ & $9.96 \mathrm{a}$ & $42.30 \mathrm{~b}$ & $3.20 \mathrm{a}$ & $63.96 \mathrm{a}$ \\
\hline & $\begin{array}{c}\text { Level of } \\
\text { Significance }\end{array}$ & $* *$ & ns & $* *$ & ns & ns \\
\hline
\end{tabular}

Treatment means with the same letter(s) are not significantly different from each other at 5\% level

(Duncan's Multiple Range Test [DMRT ]). 
$\mathrm{Cl}$ and $\mathrm{Mn}$ antagonism in EC seedlings as observed in both cultivars.

Also, it was noted that unfertilized seedlings (control treatment) from both EC cultivars have high leaf $\mathrm{Mn}$ and were significantly different from the other treatments. Possibly, the $\mathrm{MnSO}_{4} \cdot 4 \mathrm{H}_{2} \mathrm{O}$ contained in the embryo culture growth medium (in vitro stage) of the seedlings had provided adequate supply of micronutrient $\mathrm{Mn}$ to support further growth and development of EC seedlings in nursery.

Overall, these results clearly showed that the EC Laguna Tall and Makapuno seedlings responded positively to the combined application of common salt (sodium chloride) and chicken manure $(\mathrm{CM})$ to supply significant amounts of $\mathrm{N}$, $\mathrm{P}, \mathrm{K}, \mathrm{Cl}, \mathrm{Ca}, \mathrm{Na}, \mathrm{Mg}, \mathrm{S}, \mathrm{B}$, and $\mathrm{Fe}$ beneficial to EC seedlings' growth and development. Moreover, the improvement in the vegetative growth characters particularly in terms of girth, plant height and total living fronds produced with treatments with sodium chloride and CM could be well explained by the significant beneficial levels of macro- and micronutrients supplied by fertilizer combination used in this crop nutrition and fertilization management study on the EC seedlings of the two cultivars.

\section{Conclusions and recommendations}

Effects of different fertilizer combinations of sodium chloride (common salt) and chicken manure as cheaper, effective and efficient sources of nutrients as $\mathrm{Cl}, \mathrm{N}, \mathrm{Ca}$ and $\mathrm{B}$, among others for the growth of embryo cultured (EC) coconut seedlings was studied. This was carried out in two nursery trials using the local typical soil (volcanic ash-rich Guinobatan silt loam) at the PCA-ARC in the Province of Albay, Bicol region, a highly suitable wet growing zone of coconuts in the country.
Results of Trials 1 and 2 indicated that the initial amount of sodium chloride (common salt) and chicken manure during the 2-month stage of the embryo cultured coconut seedlings grown on soil should be within $2-6 \mathrm{~g} \mathrm{NaCl} /$ seedling and $50-150 \mathrm{~g}$ chicken manure/seedling. The amount should be doubled in the next 4-month growth stage and succeeding 6,8 and 10 months' growth stages.

The application of sodium chloride (common table salt) at $18-54 \mathrm{~g} /$ seedling and chicken manure at $250-750 \mathrm{~g} / \mathrm{seedling}$ produced better growth of seedlings over the unfertilized ECLAGT and ECMAKT seedlings.

Moreover, the better growth of seedlings, particularly indicated by its girth, plant height and total living fronds produced were significantly associated with adequate levels of leaf $\mathrm{N}, \mathrm{P}, \mathrm{K}, \mathrm{Cl}, \mathrm{Ca}, \mathrm{Na}, \mathrm{Mg}, \mathrm{S}, \mathrm{B}$, and $\mathrm{Fe}$ (leaf \#4).

Also, this study clearly indicates the benefit and the need of applying a combination of sodium chloride and chicken manure even at moderate rates (total of $18 \mathrm{~g} \mathrm{NaCl} /$ seedling and $250 \mathrm{~g} \mathrm{CM} /$ seedling, respectively) divided equally during the 12-month nursery stage (Figure 3) for proper nutrition and fertilization management of embryo cultured coconut seedlings.

Finally, another experiment, using another soil type, comparing the best recommendation from the earlier study 1 (inorganic NPK 14-1414 fertilizer) and from this study 2 (best rates of common salt $\mathrm{NaCl}$ and chicken manure fertilizers combination deserves attention. With results from two distinct soils, this will provide reliable basis to 


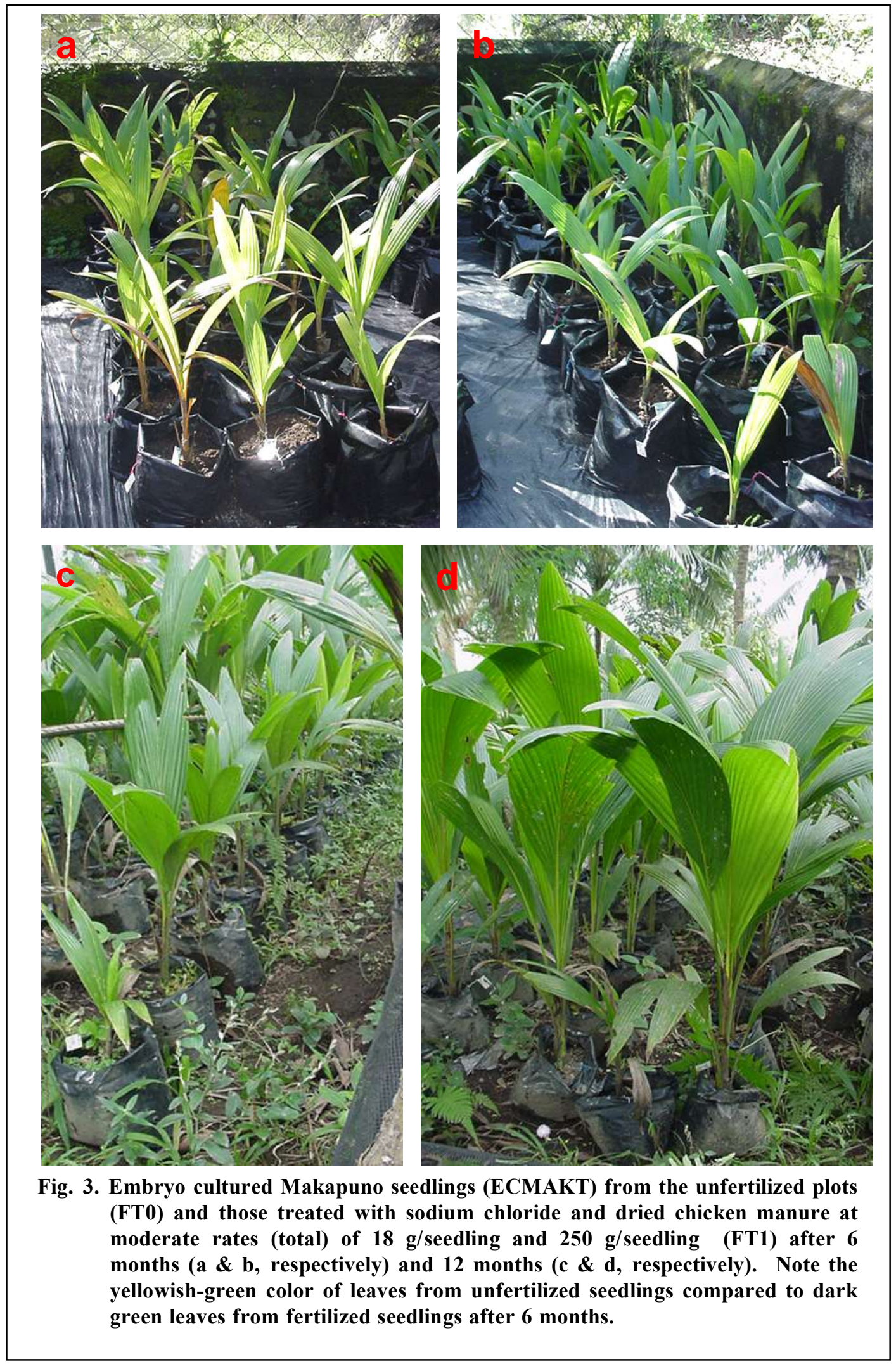


further substantiate and conclusively determine the crop nutrition and fertilization management practice that is capable of optimizing healthy, quality EC seedlings. Following an integrated EC seedling management, based on their effectiveness and efficiency, including the economics and local availability of fertilizer sources to supply the critical crop nutrition of EC seedlings, a working guide on location-specific crop nutrition and fertilization management for EC coconut seedlings could be developed.

\section{Acknowledgement}

The authors wish to express our appreciation and gratitude to $\mathrm{Mr}$. Nilo $\mathrm{M}$. Navarro, Laboratory Aide II, for his hard work in the establishment and maintenance of Makapuno embryo cultures in the laboratory, screen house and nursery and for his patience in gathering the data. Thanks are due to the other staff of the Tissue Culture Division of PCA-Albay Research Center for their support in many ways in order to finish this study and to Ms. Carmelita D. Pabustan, Division Chief III, and her staff of the PCA-Plant Tissue Analysis Laboratory, Diliman, Quezon City for the analysis of the leaf samples. Finally we thank Philippine Coconut Authority for the financial support extended to the project.

\section{References}

Areza-Ubaldo, M.B., Magat, S.S., Rillo, E.P. and Secretaria, M.I. 2005. Nutrition and fertilization management of embryo cultured Makapuno Tall (ECMAKT) seedlings. Cord 21(1): 84-94. In: Abstracts of papers presented at the $18^{\text {th }}$ Scientific Conference of the Federation of Crop Science Societies of the Philippines. Lapasan, Cagayan de Oro City. 2-6 May 2005. Philipp. J. Sci. 30(1):51.

Cadigal, V.L., Oguis, L.G. and Maravilla, J.N. 1986. Fertilization of MAWA hybrid seedlings with animal manures and other organic fertilizers. 1986 Annual Report. Agricultural Research and Development Branch, PCA, Diliman, Quezon City, pp. 30-36.
Magat, S.S. 1999. Handbook on Fertilizer Recommendations for Coconut and Selected Intercrops. Asian and Pacific Coconut Community, Jakarta, Indonesia: $150 \mathrm{pp}$.

Magat, S.S. and Margate, R.Z., 1990. The Chlorine Needs of Coconuts. Cord 6(1):30-51.

Magat, S.S., Margate, R.Z. and Prudente, R.L. 1977. Utilization of common salt (sodium chloride) as a fertilizer and for the control of leaf spot disease of coconut seedlings. Philipp. J. Cocon. Stud. 2(3):39-45. Also see Oleagineux 30(10):413-418.

Magat, S.S. and Prudente, R.L. 1975. Progress of mineral nutrition studies in the Philippines. FAO Technical Working Party on Coconut. Kingston, Jamaica (Sept. 1975). 15pp.

Magat, S.S. and Recel, M.R. 2000. Micronutrient soil status and fertilization in selected crops. Occasional S \& $\mathrm{T}$ Paper Series. No. 6. Agricultural Research Development, PCA, Diliman, Quezon City, 21pp.

Margate, R.Z. and Magat, S.S. 1991. Research guide on the conduct of agronomic and nutrition studies in coconut. Los Baños, Laguna: PCARRD. 19pp (Book Series No. 119).

Maravilla, J.N. 1986. Nutrition and fertilization of coconut seedlings in polybags. Philipp. J. Cocon. Stud. 11(1):44-56.

Oguis, L.G., Magat, S.S. and Margate, R.Z. 1979. The effect of chlorine sources and ammonium sulfate on the growth of coconut seedlings. Philipp. J. Cocon. Stud. 4(3):25-39.

Rillo, E.P. and Paloma, M.B.F. 1992. In vitro culture of Makapuno coconut embryos. Coconuts Today 9(1):90-101. 
Cord 2006, 22 (2)

Secretaria, M.I. and Maravilla, J.N. 1997. Response of hybrid palms to application of manures and fertilizers from field-planting to full-bearing stage. Plantations 4(2): 126135. 